membered that, yes, she once did have a son whose name was Horace or Henry or Harold. Those were the only choices available at the time. Today young people are so different, she said. They don't seem to be afraid of anything: the whole alphabet, nightfall.

\title{
Sense of Injury
}

\section{Jeremy Shaw}

Yesterday I killed a tree. Just a little one, to be sure-I didn't think I could kill a big one. I pulled it up by its roots and cut it up with an axe into small pieces which I then dropped down the sewer. I watched it go down. I know, too, a little about the light haired girl who lives a mile down the road. Her name is Jennifer.

As the leaves change, every year, I see her in the distance on her mare. But I almost never get close to her.

My father says I am blocking the sewer with all that wood.

I go fishing, sometimes. The other day I was fishing, killing even the smallest ones-then throwing them back to watch them come to life again-down near the place where the stream falls, where Jennifer sometimes waters her mare. She was swimming, this time. She was alone.

She has long hair and it was wet. Then I hooked a big trout and when I looked again she was gone. So I went down there myself and swam, afterwards, leaving my clothes where she had left hers. I hope she was watching, but I don't know that she was. Wouldn't it be something if she did see me? I'll go there again. I hope she will, too.

Today I was allowed to slaughter a hog. My father says I'll have to learn how to do it all, eventually, and so I might as well start now. There was a lot of blood and a lot of screaming. If anything has real pain when it's dying, it's a hog. 
You've never heard anything like it. My father says I did a good job and can help him every time, now-even, perhaps, with the next steer.

Yesterday I saw her again. I had pulled in a big one, a huge devil with teeth all over him. He died slowly, as big fish do, and twice I revived him, putting his head back under water-almost losing him once. They say that some fish can bite your hand off, if you're not careful. When he was dead I took him to the place where Jennifer had left her clothes that time and left him there, so she would see him if she came. She did come. But for some reason she didn't go in swimming. Perhaps she wondered who left her the fish. Perhaps I should have left a note there with it saying it was only me-so she could have gone in again. Maybe if I'm down there myself, next time, she'll go in with me. I'll have a bloodier fish for her. The biggest in the river. I could make it all red-all over the rock.

She looked over the top of the falls but didn't go down.

This is very different from any feeling that I've ever had, before. My father says that I'll settle down and get married one day, and help him with the farm, and have grandchildren for him. I don't know why he says that-but it isn't any of my business to ask. I'm rather glad, now, that I live near her.

Perhaps she doesn't like the fish at all, and I shouldn't leave another one.

This evening I feel very strange. It is as though, suddenly, I'm overfilled with myself. Yes, tonight I have more blood in me than ten hogs and it's a deeper red.

It is because of what happened today, I suppose.

We killed the steer, first thing in the morning. I hadn't been down to the swimming place for almost a week because work being done around the farm. My father is making me do more and more. We took the steer into the barn and tied him up so that he could hardly move, and he bellowed all the time until he was dead. My father told me that in the big stockyards they herd the cattle in one by one, thousands of them, and as they go in someone who is standing there hits each one on the head with an axe-like thing that has a point on it. They do that all day. The steer falls on to a conveyer belt-like the ones they use for hayand is taken to another part of the plant where he is cut up into pieces. The noise must be terrific.

He was showing me how it is done and he missed the right place with the first hit. The steer really bellowed, then. The next hit, though, killed him but there was still a lot of blood. We are going to cut him up tomorrow.

One day I'll be able to do that.

It made me feel so good that in the afternoon I wanted very badly to see Jennifer again. So I went down there and hid behind a rock hoping she would come. I just wanted to see her. I think I would always like to see her, swimming there. Perhaps that's what it's like being married, as my father wants for me.

She came, after a while, and left her clothes on the rocks again. It was so 
good seeing her that I couldn't stay hidden for very long. I came out of my hiding place and went over to where her clothes were. I called out to her that I was going to come in with her, that she should wait for me. I told her that I had often watched her there, that I really liked to see her-that it was I who had left her the fish that time. She called back to me to go away, but I said I didn't want to do that. I told her I liked her and that was why I had come. I told her about the steer and how it made me feel, but she still said to go away. I said, then, that I was going to come in with her, right away. I don't know why but she cried out in a strange way and climbed out of the pool on the other side and started to run downstream along the bank. I wanted to tell her to stay, that I wanted to swim with her and that I liked her, so I ran around by the crossing and followed her.

I caught her, not too far away-I am quite fast, running-and made her stop. I held on to her arm and asked why she had run away, but she only struggled and cried. So I took her to the little hut, where the stream turns-where I used to go when I ran away from my father-and asked her if she would stay there until next morning because I had to go home to supper. But she didn't say anything and was crying still, so I boarded up the door and the windows with the nails and tools that I always keep there and came on home.

Now I can swim with her whenever I want to.

It is very late, now. But I can't sleep because of thinking of her there. I know how she must look-how she must be tidying up the hut as my mother used to do here and cooking herself something to eat. I can't remember if there is any food there, but there are pots and pans and things and lots of wood outside for a fire. I remember seeing a picture in a book, when I was going to school, of a woodsman and his wife living a happy life in a cottage in a wood somewhere.

That's how I feel-just like in the picture.

There is a place where I sit, now, on the hill overlooking the wood where the hut is. There are ants, still, underneath where I sit-but I don't really like killing them any more. I sit here almost every day, sometimes for hours at a time. I am very close to her. I have been coming here for months, now.

I know she's still in the hut; she couldn't get out. We are the only two people in the world. I don't care about other people.

One day I'll go down there, again. 